\title{
Plato, Xenophon, and the Laws of Lycurgus
}

\author{
Malcolm Schofield \\ Emeritus Professor of Ancient Philosophy, St John's College, \\ Cambridge University, Cambridge, UK \\ ms1ooor@cam.ac.uk
}

\begin{abstract}
The relation between the opening section of Plato's Laws and Xenophon's Constitution of the Lacedaemonians usually goes unnoticed. This paper draws attention to its importance for understanding Plato's project in the dialogue. It has three sections. In the first, it will be shown that the view proposed by Plato's Athenian visitor that Lycurgus made virtue in its entirety the goal of his statecraft was anticipated in Xenophon's treatise. It has to be treated as an interpretation of the Spartan politeia, alternative to that advanced by Cleinias and Megillus, and accepted by (for example) Aristotle, which Plato could expect or at any rate hope to be taken seriously as such. In the second, the argument will focus on the contents of the legislative programme the Athenian says he had hoped to hear Cleinias ascribe to the Cretan and Spartan lawgivers. The case will be made that Plato can expect recognition by the reader (as by the Athenian's interlocutors) that the programme is properly Spartan and Cretan by virtue of its echoes of the programme attributed to Lycurgus by Xenophon. Finally, the third section will argue that in making law primarily concerned with fostering the proper development, conduct, and treatment of human beings at every stage of the life cycle, above all by provision for sound customary practices ( $\dot{\varepsilon} \pi \imath \eta \delta \varepsilon \dot{\mu} \mu \alpha \tau \alpha)$ and the like, Plato adopts the approach to law making taken by Xenophon's Lycurgus.
\end{abstract}

\section{Keywords}

Crete - custom - law - lawgiver - Lycurgus - Plato - Sparta - writing - Xenophon

This paper develops arguments for seeing engagement with the short treatise we know as Xenophon's Constitution of the Lacedaemonians as something that helped Plato shape the approach to law and legislation taken in the Laws. 
That title for Xenophon's work is the way it is designated in the manuscript tradition. But as Vivienne Gray comments: 'Politeia may not be the original title (Lac. uses it [sc. the word] only once, and in reference to the constitutions of other poleis: 15.1$)^{\prime}{ }^{\prime}$ As likely - I think in fact more so - is that Xenophon called it $\Lambda$ uxoúpyou vónol, 'The laws of Lycurgus': for that is what at the outset (Lac. 1.2) and throughout he makes his explicit focus. Plato's titling of his own last dialogue as simply vónol, Laws, could then be viewed as following his

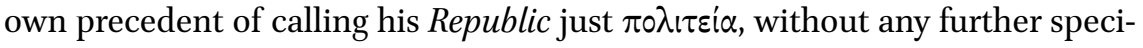
fication such as 'A $\eta v \alpha i \omega v$, 'Political system of the Athenians', where that title for the Old Oligarch's tract is made likely by the specification of that topic in its very first words.

However that may be, my focus here is on the opening pages of the Laws. The dialogue begins with a critique by Plato's main speaker, an Athenian visitor to Crete, of the conception of the proper goal of statecraft as preparedness for war, as is attributed by his host Cleinias to Minos and Lycurgus, traditionally regarded as authors of the Cretan and Spartan laws. The Athenian instead proposes virtue - the whole of virtue, not just courage - as the right goal. Moreover, he insists that that idea must actually have been what governed Cretan and Spartan lawgiving. This further claim is sometimes not taken very seriously by scholarship. Susan Sauvé Meyer, in her recent commentary on Books 1 and 2 of the Laws, is probably not atypical of many in thinking of it as a 'conceit'. I shall argue on the contrary that it expresses a seriously held alternative ideological construction of Lycurgus's intentions at Sparta that Plato was not alone in championing. In short, the overarching goal of the Spartan $\pi \circ \lambda ı \tau \varepsilon \dot{\alpha} \alpha$ really was a contested issue. ${ }^{3}$

Xenophon's account of the laws of Lycurgus will play a key role in the development of the case I shall make. The paper has three sections. In the first, it will be shown that the view proposed by Plato's Athenian visitor that Lycurgus made virtue in its entirety the goal of his statecraft was anticipated in Xenophon's treatise. It has to be treated as an interpretation of the Spartan politeia, alternative to that advanced by Cleinias and accepted by (for example) Aristotle, which Plato could expect or at any rate hope to be taken seriously as such. In the second, the argument will focus on the contents of the legislative programme the Athenian says he had hoped to hear Cleinias

1 V.J. Gray, Xenophon on Government (Cambridge: Cambridge University Press, 2007), p. 146.

2 S.S. Meyer, Plato: Laws 1 \& 2 (Oxford: Oxford University Press, 2015), p. 105.

3 See S. Hodkinson, 'The imaginary Spartan politeia', in M.H. Hansen (ed.), The Imaginary Polis (Copenhagen: The Royal Danish Academy of Arts and Sciences, 2005), pp. 222-81, at pp. 222-7. 'In late fifth-century Athens, in particular', he writes (p. 225), 'the Spartan polis was a battleground of competing imaginations.' 
ascribe to the Cretan and Spartan lawgivers. The case will be made that Plato can expect recognition by the reader (as by the Athenian's interlocutors) that the programme is properly Spartan and Cretan by virtue of its echoes of the programme attributed to Lycurgus by Xenophon. Finally, the third section will argue that in making law primarily concerned with fostering the proper development, conduct, and treatment of human beings at every stage of the life cycle, above all by provision for sound customary practices (i் $\pi \imath \eta \eta \delta \varepsilon \dot{\mu} \mu \alpha \tau \alpha)$ and the like, Plato adopts the approach to law making taken by Xenophon's Lycurgus. ${ }^{4}$

Before these ideas are developed, however, something needs to be said about the Cretan system. Cleinias, the representative Cretan participant in the discussions conducted in the dialogue, is the Athenian's principal interlocutor, and his first sustained contribution to the conversation is entirely devoted to Cretan institutions, appropriately so given the question put to him (Leg. 1.625c-626b). He is ready at once to extend his account to Sparta. But Megillus is treated as the junior Dorian partner throughout the dialogue. ${ }^{5}$ So one might have expected that Plato would have wanted to use an account of the Cretan politeia alternative to Cleinias's. Perhaps he would. But perhaps there was none, or at any rate any that he could find.

The very existence of such a thing as 'the Cretan politeia' is debatable. Plato, Aristotle, and their contemporary the historian Ephorus all speak as though there was. Yet in the fourth century BC there were many self-governing cities (Paula Perlman documented forty-nine archaic and Classical poleis). ${ }^{6}$ Perlman's view was that a single template for the 'Cretan politeia' was created in the late Classical period, probably by philosophers, which underlies the fourth century

4 A recent study by N. Humble, 'Sparta in Plato and Xenophon', in G. Danzig, D. Johnson, and D. Morrison (eds.), Plato and Xenophon: Comparative Studies (Leiden and Boston: Brill, 2018), pp. 547-75, focuses 'primarily, though not exclusively, on Plato's Republic and Xenophon's Spartan Constitution' (p. 548), but does see in Megillus's accounts of the ephorate as tyrannical in Book 4 of the Laws an echo of Lac. 8.4, and of key Spartan practices in a passage of Book 1, subsequent to the ones that most interest me, 'a succinct summary of Lac. 2.2-11'. She refers (at pp. 553-4 and 571) to $\operatorname{Leg} 4.712 \mathrm{~d}$ and 1.633b (on habituation to endurance of pain) respectively.

5 There was a tradition known first from Herodotus that Lycurgus actually imported his laws from Crete: Hdt. 1.65.4; cf. e.g. Arist. Pol. 2.10.1271b20-32, Strabo 10.4.17-19. Polybius (6.45.147.6), however, thought preposterous the whole idea that Spartan arrangements bore any resemblance in their essentials to Crete.

6 P. Perlman, 'Crete', in M.H. Hansen and T.H. Nielsen (eds.), An Inventory of Archaic and Classical Poleis (Oxford: Oxford University Press, 2004), pp. 1144-95. 
accounts that survive. ${ }^{7}$ Presumably its creation might have been motivated by perception of a need to justify the credibility of the alleged dependence of Spartan statecraft upon Cretan, particularly perhaps when (as Ephorus attests: Strabo 10.4.17) many Cretan cities were believed to be Spartan colonies (Lyktos, one of the most important, is asserted to be so by Aristotle: Pol. 2.10.1271b2730). Preparedness for war is a dominant theme in the accounts of the Cretan system given by Plato's Cleinias, and Ephorus (Strabo 10.4.16), while Aristotle early in his account stresses Minos's acquisition, whether by conquest or by colonisation, of a maritime empire (Pol. 2.10.1271b37-40). The Athenian's alternative is nowhere detectable in these narratives.

\section{$1 \quad$ Two Views of Lycurgus's Lawgiving}

The opening pages of the Laws contrast two different conceptions of what the Cretan and Spartan lawgivers (Minos and Lycurgus) were aiming to achieve in their legislation. One view is advanced by Cleinias. When asked about the communal meals, physical training, and arms bearing required of his countrymen, he relates them all to military campaigning. That in turn he relates to 'a lifelong and continuous state of war against all other cities' (Leg. 1.625e) 'the natural state of affairs' (626a). The lawgiver 'framed all our institutions, in the private and public spheres, with war in view' (626a).

So far so Cretan. But when it is put to him that his position might be crystallised in a definition or defining characteristic (öpos) of a well-ordered city, as one so constituted as 'to overcome the other cities in war', Cleinias is made not only to give his own assent, but also to associate with it that of the representative Spartan present (Megillus). Megillus takes up the cue, and makes his first contribution to the conversation: 'What other answer could any Lacedaemonian possibly give?' (Leg. 1.626c). A little further on we find him endorsing a claim by Cleinias (628e) that what he has said about Crete is true also of the Spartan lawgiver's invention of the same institutional practices: 'with war in view' (633a).

An alternative view is put by the dialogue's leading speaker, an Athenian visitor to Crete never given a name. Following his critique of Cleinias's account, we get the following passage of dialogue:

7 See P. Perlman, 'Imagining Crete', in M.H. Hansen (ed.), The Imaginary Polis (Copenhagen: The Royal Danish Academy of Arts and Sciences, 2005), pp. 282-334, at pp. 282-7. 
Cleinias: Does that mean rejecting our Cretan lawgiver, my friend? Does it put him among lawgiving's also-rans?

Athenian: Don't be offended, my friend, we are not rejecting him. But we turn ourselves into also-rans if we think Lycurgus and Minos made their legal arrangements, in Sparta and here in Crete, principally with a view to war.

Cleinias: What should we actually have said?

Athenian: I think we should have said what was true, and what was right in a discussion of a man inspired: that he did not set about legislating with an eye to just one part of human goodness - and the least important part at that - but with an eye to goodness as a whole $(\pi \hat{\alpha} \sigma \alpha \nu$

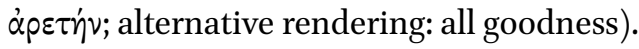

Leg. 63 od $-\mathrm{e}^{8}$

The Athenian then gives his own detailed account of how Spartan and Cretan legislation should be described on that ethical basis. ${ }^{9} \mathrm{He}$ concludes as follows:

That, my friends, is what I would have liked from you - what I want from you now, come to that - an explanation how all this is contained in the laws attributed to Zeus and Pythian Apollo, the work of the two lawgivers Minos and Lycurgus, and how they possess a degree of ordering which is immediately apparent to the person who has a familiarity with laws either by formal training or by dint of some habitual practices - though it is not in the least clear to the rest of us.

Leg. $632 \mathrm{~d}$

It is often assumed that the Athenian's alternative has in reality nothing much to do with anything credibly attested for Cretan or Spartan legislation or otherwise believed about it. It is taken to be a purely Platonic construction.

8 Translations from the Laws are mostly those by Tom Griffith, occasionally adapted, in M. Schofield and T. Griffith (ed. and trans.), Plato: Laws (Cambridge: Cambridge University Press, 2016).

9 In subsequent dialogue with Megillus (Leg. 1.632e-633a), just after reiterating that 'all the things we have just been talking about have goodness as their aim', he asks: 'So tell me, these meals you have all together, and the physical training, are we saying they were an invention of the lawgiver to meet the needs of war?' Hodkinson reads this implausibly as expressing agreement on the claim on the part of the two them ('The imaginary Spartan politeia', p. 251); better is E.B. England, The Laws of Plato, Books I-VI (Manchester and London: Manchester University Press, 1921), p. 221. 'We' is the 'we' who are at this point putting forward ideas in shared conversation for discussion and criticism by ourselves. 
There is reason, however, to think that these opening pages of the Laws do reflect competing interpretations of the Spartan politeia, at any rate, that were espoused more widely in the fourth century BC. View A (that advanced by Cleinias and Megillus) is attributed by Aristotle to a Spartan writer he names as Thibron 'and to everyone else who has written on their politeia', in general with admiration (Pol. 7.14.1333bi1-21). Like Plato in the Laws (whom he has cited on the matter in Book 2.9,1271a41-b3), he is highly critical of any such notion as an appropriate candidate for constituting the telos of a politeia. But unlike Plato he takes it to be a correct construal of the basis on which the Spartan polity was constructed, and has savage things to say about their legislator (Pol. 2.9.1271b3-19, 7.14, 1333b21-1334a1o). ${ }^{10}$ View B (the alternative urged by the Athenian on his interlocutors) also had at least one advocate: Xenophon.

For the evidence of View B in Xenophon, we need to turn to that short work

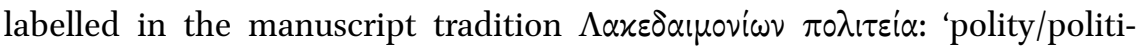
cal system of the Lacedaemonians.' Xenophon launches his little treatise by referring to his reflections on the 'customary practices of the Spartiates' ( $\tau \dot{\alpha}$

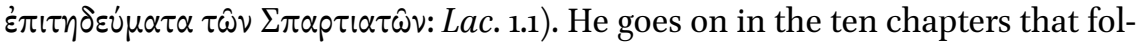
low that introduction to treat these as established through the nomoi ( $\nu \delta^{\mu \circ \mathrm{l}}$ )

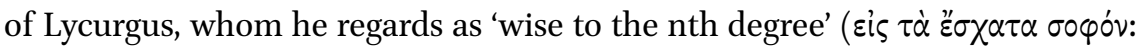
Lac. 1.2). The outcome of Lycurgus's work was to make his native country an object lesson exceeding most others in eudaimonia, well-being (Lac. 1.2). Chapter Ten of the work provides a kind of summing up of his intent and achievement. Cultivating virtue could not be left a voluntary matter: the virtuous do not then have the capacity to strengthen ( $\alpha \nu \xi \varepsilon v)$ their countries. So

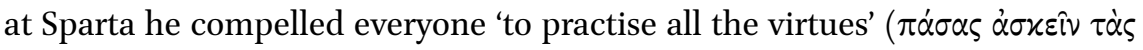
$\dot{\alpha} \rho \tau \tau \dot{\alpha} \varsigma)$ in public life. That is why Sparta probably surpasses all cities in virtue,

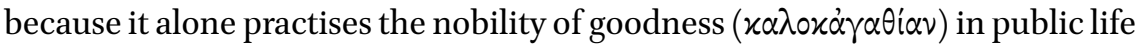
(Lac. 10.4). People were punished for evidently not making the effort to be 'as good as possible' ( $\dot{\omega} \beta \hat{\beta} \lambda \tau \tau ا \sigma \tau o \varsigma ~ \varepsilon i v \alpha l: ~ L a c . ~ 10.5)$. Lycurgus made it an indispensable necessity for people 'to practice the whole of citizen virtue' ( $\dot{\alpha} \sigma \kappa \varepsilon i \nu \tilde{\alpha} \pi \alpha \sigma \alpha \nu$

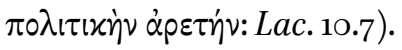

What has preceded this assessment has been an account that focuses almost entirely on the provisions Lycurgus made for producing children with the required natural endowment, for their subsequent upbringing and induction into the rigours of Spartan manhood, and for the communal life of the city. At the public meals, talk should be of 'whatever someone has done nobly

10 See further my discussion in 'Aristotle's critique of Spartan imperialism', in P. Cartledge and A. Powell (eds.), The Greek Superpower: Sparta in the Self-Definition of Athenians (Swansea: The Classical Press of Wales, 2018), pp. 215-34, at pp. 216-20. 
in the city'; the accent is on mutual respect, and avoidance of drunken carousing (Lac. 5.6). Lycurgus' general aim was to ensure that the citizens enjoyed mutual benefit without causing harm (Lac. 6.1). They must have nothing to do with making money, but concentrate on activities that equip cities for freedom (Lac. 7.2). Xenophon then devotes a chapter (Chapter 9) to the methods Lycurgus employed to make well-being contingent on being 'good' (à $\gamma a \theta o$ s), which in context sounds more or less equivalent to 'brave' (cf. 4.6; also 4.1:

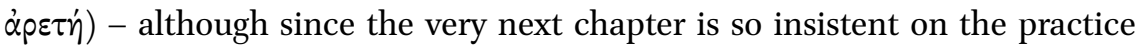
of the whole of citizen virtue, it may be that courage in warfare is seen only as the most important form of that virtue. He instituted an entire concerted programme of measures ensuring that the life of the 'bad' would be thoroughly miserable.

The military ethos of the Spartan polity is therefore by no means denied or downplayed. ${ }^{11}$ Chapters 11 to 13 will indeed go on to the organisation of the army and to the other provisions for the conduct of war instituted by Lycurgus. But those chapters are presented as a sort of appendix to the main account Xenophon has given, which has described practices 'beneficial communally both in peace and in war' (Lac. 11.1). ${ }^{12}$ The appended chapters - conceivably a later addition (they talk of Lacedaemonians, not as hitherto Spartiates) - are provided expressly to satisfy the curiosity of someone wishing to know how Lycurgus's military dispositions for the army when on campaign were better than other systems. There is no indication that war, victory in war, and military conquest were to be the country's telos, as they were according to View A. Xenophon has it that Lycurgus's goal was well-being for the city and all the citizens, to be achieved by their common noble practice of the whole of virtue - all the virtues. In other words, he clearly takes View B.

A later proponent of View B was Plutarch, in the essay he devotes to the life of Lycurgus. Here is how his concluding chapter starts

11 The terms with which initial reference to the introduction of common meals are made ( $\sigma \nu \sigma x \eta v o u ́ v \tau \omega \nu, \sigma v \sigma x \eta \dot{v} \alpha:$ Lac. 5.2, 4) have the military associations of 'tenting together', although Xenophon reverts to the more usual $\varphi(\lambda i \tau \iota \alpha$ subsequently (Lac. 5.6). In fact he begins his discussion by remarking that Lycurgus had found the Spartiates 'tenting at

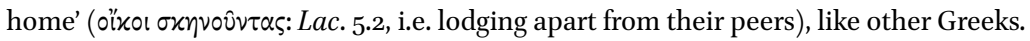

12 Herodotus makes Lycurgus first change all the Spartans' vó $\mu \mu \alpha$ and put in place measures to ensure compliance with those he was introducing, but has him deal only subsequently with military organisation and the common meals, and finally with the institution of the ephorate and $\gamma \varepsilon$ povtí $\alpha$ (Hdt. 1.65.5). 
It was not, however, the chief design of Lycurgus at that time to leave his city exercising hegemony over a great many others, but he thought that the well-being of an entire city, like that of a single individual, depended on the prevalence of virtue and concord within its own borders. The aim, therefore, of all his arrangements and adjustments was to make his peo-

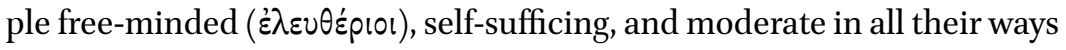

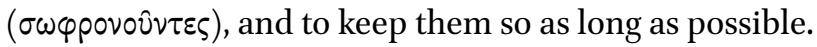

Lyc. $31.1^{13}$

'At that time' refers to the point at which (according to Plutarch) Lycurgus considered that he had completed the essentials of lawgiving, and departed to Delphi to seek their endorsement by the oracle, where he asked, 'whether the laws which he had established were good, and sufficient to promote a city's well-being and virtue'. Apollo supplied the endorsement, and Lycurgus decided this was the point at which he should put an end to his own life (Lyc. 29.3-4; cf. 8.5).

Plutarch was doubtless aware that View A had its advocates. 'Exercising hegemony' over other Greeks (Lyc. 31.1) sounds as though it might be a formulation of an alternative interpretation of Lycurgus's intent incompatible with his own. 'Hegemony' (so described) was precisely what Aristotle, one of View A's proponents, thought that both Athens and Sparta had achieved and sought to use for their own advantage; and to his mind the Spartans were only thereby carrying out the design of their lawgiver (Pol. 4.11.1296a32-6; cf. 2.9.1271b3-19, 7.14.1333b21-1334a10). Whether Plutarch knew of that assessment we do not know; and hegemonic ambition or control was a not unfamiliar diagnosis of the realities of power in the Aegean (e.g. Isoc. On the Peace 3o, Xen. Hell. 7.1.33, Dem. Phil. 3.23). But he does begin his whole account of Lycurgus with an acknowledgement of a kind comparatively rare among ancient Greek and Roman authors:

Concerning Lycurgus the lawgiver, in general, nothing can be said which is not disputed, since indeed there are different accounts of his birth, his travels, his death, and above all, of his work as lawmaker and statesman.

Lyc. 1.1

13 Plutarch, Lives, Vol. 1. Trans. B. Perrin (with minor adaptations) (Cambridge, MA: Harvard University Press, 1914). 
A later chapter does provide specific evidence of contrary claims about Lycurgus's involvement in warfare and its bearing on his lawgiving:

Hippias the Sophist says that Lycurgus himself was very well versed in war and took part in many campaigns, and Philostephanus attributes to him the arrangement of the Spartan cavalry by 'oulamoi', explaining that the 'oulamos', as constituted by him, was a troop of fifty horsemen in a square formation. But Demetrius the Phalerean says he engaged in no warlike undertakings, and established his constitution in a time of peace.

Lyc. 23.1

Plutarch does not come down on either side, although he gives what might be interpreted as a suggestive indication that he would prefer Demetrius to have been right.

No doubt View A and View B were both espoused in different variants. Most obviously, and most pertinently for the purposes of this article, there is divergence in the presentation of View B: Plato's Athenian takes the line that on a proper assessment of the Spartan and Cretan legislators' intentions, courage is to be conceived as 'the least important part' of virtue (Leg. 1.63oc-631d); Xenophon more plausibly and certainly less provocatively gives it an emphasis in Lycurgus's lawmaking that one might have expected. That said, the Athenian does begin his own substantive treatment of virtue by tackling courage first of all (Leg. 1.632d-e; indeed, courage remains the main subject of Book 1), while on the other hand it is not accorded a central position in Xenophon's account. The chapter he devotes to the topic begins: 'This too is a provision made by Lycurgus that deserves admiration' (Lac. 9.1). We may contrast the more prominent focus in Book 1 of the Laws on the Spartan poet Tyrtaeus's verses on courage in battle with external enemies, the virtue which the Athenian gets Cleinias, a proponent of View A, to associate without hesitation with the outlook of the Cretan legislator (Leg. 1.629a-e, 63oc-d). Aristotle, likewise an advocate of View A, goes further. He implies a resemblance between the Spartans and the savage peoples of the Black Sea area, who are given to mere banditry, and are on his assessment entirely lacking in courage - i.e. true courage (Pol. 8.4.1338b19-24). Spartan success in warfare was due to their train-

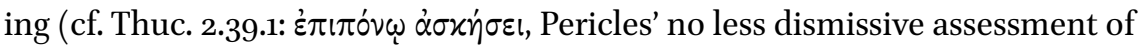
their pursuit of bravery), whereas 'nobility of character rather than ferocity of disposition should play the principal part' (Pol. 8.4.1338b24-30). 
Plato and Xenophon are aligned in presenting View B as the correct interpretation of Lycurgus's intent as Spartan lawgiver. For both of them his provisions were designed to promote 'the whole of virtue'. It would be hazardous to conjecture that Plato's espousal of View B was prompted by Xenophon's, although the Laws was probably composed after Xenophon's death, and certainly well after the likely circulation of the work we know as 'The polity of the

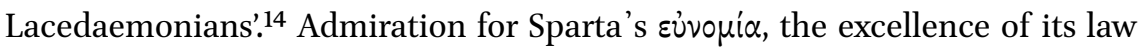
governed polity, is professed in the Crito by Plato's Socrates (or rather, ascribed to him by the laws of Athens that he imagines as addressing him: Crito 53a). There is every reason to suppose that discussion of that euvopía would often have occurred in Socratic circles in the fourth century. And it would not be a surprise if other Socratic authors besides Xenophon and Plato wanted to credit Lycurgus, as a wise lawgiver, with something approximating a Socratic unity of virtue. Perhaps it was even a supposition generally entertained by those who embraced some version of Socratic philosophy.

Nonetheless there is a specific feature of Plato's presentation of the work of the Cretan and Spartan lawgivers in the Laws which does argue for indebtedness on his part to Xenophon in particular, among authors for whose writing on Sparta we have evidence that might be relevant. This is the itemized programme of legislation his Athenian outlines in his account of what Cleinias should have attributed to Lycurgus and Minos. To see why the Xenophon treatise on Sparta discussed in Section 1 may be important here, a close look at a not altogether straightforward passage of Book 1 at the end of that account is first needed. Only then can the idea of Xenophon's silent presence be introduced.

The Athenian rounds things off by saying to Cleinias and Megillus, with words already quoted in Section 1 :

That, my friends, is what I would have liked from you - what I want from you now, come to that - an explanation how all this is contained in the laws attributed to Zeus and Pythian Apollo, the work of the two lawgivers

\footnotetext{
14 All relevant dates are conjectural. The Laws is usually thought to be Plato's latest dialogue, mostly belonging to the late $35 \mathrm{Os} \mathrm{BC}$. Xenophon's death is often dated to around 354. Dates suggested by different scholars for composition of the Constitution of the Lacedaemonians vary greatly, complicated by the hypothesis advanced by some that chapter 14 (near the end), reflecting on Sparta's current condition, is a later addition composed after the Spartans' catastrophic defeat at the battle of Leuctra (371). Gray, Xenophon on Government, p. 43, favours the 36 os; she argues that chapter 14 is integral to the work as a whole, pp. 217-21.
} 
Minos and Lycurgus, and how they possess a degree of ordering ( $\tau \dot{\alpha} \xi \mathrm{t}$ $\tau \imath \dot{\alpha})$, which is immediately apparent to the person who has a familiarity with laws - either by formal training or by dint of some habitual practices - though it is not in the least clear to the rest of us.

Leg. 1.632d

There are two dimensions distinguished here in the prescriptive presentation (Leg. 1.631b-632c) to which the Athenian here refers back. He seems to be differentiating within it between the content, on the one hand, that he has been proposing to ascribe to the legislation of Minos and Lycurgus itself, as he is supposing it must truly be if it is to satisfy the prescription for good lawgiving that he has just spelled out; and its ordering, on the other - by which he most likely means its ranking of divine and human goods (Leg. 1.631b-d; although some scholars have taken it to be the systematic ordering of topics of legislation for different key areas of human activity and associated points within the human lifespan which follows the ranking passage: Leg. $.631 \mathrm{~d}-632 \mathrm{C}) .{ }^{15}$ It is that ordering which he says is 'not in the least clear to the rest of us'. However, his own request to Cleinias and Megillus is not as clear as it might be.

He has offered an account of (a) lawgiving as it should be; the claim that (b) Minos and Lycurgus were good lawgivers; and the inference that (c) their lawgiving will therefore have satisfied the requirements of (a). When he concludes by remarking that the ordering within the legislation is 'not in the least clear to the rest of us', does that criticism relate to (a) or (c)? (a) seems very unlikely. The Athenian would then be making an odd complaint about his own presentation: odd, since for one thing he is surely including himself among 'the

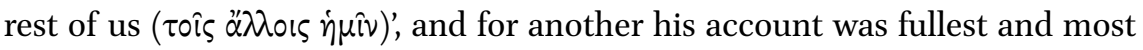
specific precisely in its treatment of the hierarchy of goods.

So presumably his comment effectively relates to the idea in (c) that Dorian, i.e. Cretan and Spartan, laws did meet the standards of good legislation outlined in (a). That is what the Athenian thinks will be 'immediately clear' to legal experts, but far from clear to others, himself included. The two most recent commentators on Book 1 of the dialogue both read it that way. Schöpsdau does not think Plato means to be understood as denying that some Dorian legislation actually does fit the appropriate template (although he notes that

15 So K. Schöpsdau, Platon:Nomoi, Buch I-III (Göttingen:Vandenhoeck and Ruprecht, 1994), p. 19o, Meyer, Plato: Laws $1 \&$ 2, p. 120, pointing out that the Athenian has employed this vocabulary of $\tau \dot{\alpha} \xi ı$ in concluding the introduction of his hierarchy of goods (Leg.1.631b-d) at 631d. The Loeb, Budé, and Penguin translations all have 'system' or 'systematic arrangement', suggesting the possibility of other forms of structuring, e.g. by topics covered in legislation. But one would not need to be a legal expert to be able to see what they are without difficulty. 
some will also soon be accused of failing to do so: Leg. 1.634c-635b). Nor does Schöpsdau seem inclined to take very seriously the Athenian's implication that he himself does not grasp the ordering in that Dorian legislation. It is 'not without self-irony', i.e. wryly insincere, because (I suppose) he has more expertise in laws and lawgiving than he pretends to Cleinias and Megillus, who are Schöpsdau thinks - being assumed themselves to be expert. ${ }^{16}$ That assumption seems not to pay any attention to the understanding of the principles shaping the Cretan and Spartan polities that Cleinias and Megillus have advocated in the opening pages of Book 1, very different (as the Athenian has insisted) from any which would satisfy his own requirements for good lawgiving. Moreover, one is left wondering whether on this reading his statement of failure by non-experts to discern the ordering of Dorian legislation (rather than the content), for Schöpsdau something due simply to deficiency in them, packs much punch at all.

Meyer, on the other hand, talks of the Athenian persisting here in the 'polite fiction that the Dorian laws exemplify the highest legislative standards'. When he then says that to experts in laws their principles of ordering are 'immediately apparent', he is indeed being ironic. In actual Dorian laws, there simply is no order prioritizing divine over human goods visible to anyone, expert or not. ${ }^{17}$ In other words, the comments by the Athenian on who does or does not find the ordering clear are designed to puncture the entire fiction. Meyer here plausibly assumes (as does Schöpsdau) that he has in mind by 'ordering' the specific priority he has given in his own presentation (Leg. 1.631b-d) to goods that are 'divine' (the four cardinal virtues), over those that are 'human' (health, beauty, strength, wealth). Other aspects of her interpretation are questionable. There is fiction and fiction. The Cicero and Thomas Cromwell trilogies of Robert Harris and Hilary Mantel are obviously quite different sorts of fiction from Alice in Wonderland or again from The Pickwick Papers. It is not as though evidence for historical Sparta is that plentiful or secure. The claim that Dorian laws did not prioritise divine over human goods might be regarded as debatable. For example, Cleinias has mentioned the common meals as one of the lawgiver's institutions (Leg. 1.625e-626a). For him, the explanation of it is certainly couched primarily in terms of the protection of the army in war. But

16 Schöpsdau, Platon: Nomoi, Buch I-III, p. 19o; cf. pp. 198-9. England, The Laws of Plato, Books I-VI, p. 219, also speaks of 'a polite irony'.

17 Meyer, Plato: Laws 1 \& 2, pp. 121-2. She notes earlier (pp. 104-5) that in Book 2 the Athenian 'will not mince words in castigating their societies for being organized on exclusively military principles $(666 \mathrm{e}-667 \mathrm{a})$ '. But he is at pains to insist that he does not intend this as a criticism of their lawgivers - the implication being (as in Book 1) that Minos's and Lycurgus's intentions have been misunderstood and distorted by Cretans and Spartans. 
for Xenophon, Lycurgus's rationale for the same institution is exclusively moral (Lac. 5.2-7).

It may be worthwhile taking an alternative approach, then, to the Athenian's treatment of the laws of Minos and Lycurgus. This is to suppose that he is assuming at least one other well-known description of the laws of Minos or Lycurgus with recognisable similarities to the sketch of how lawgiving ought to be done that he has just spelled out (Leg. 1.631b-632d); and that it is to that sort of treatment of them that he refers in challenging Cleinias and Megillus for an explanation of how its contents and not very obvious ordering map on to his own sketch - genuinely not obvious to him, no less than to anybody else not a legal expert. If that description is prominently represented elsewhere as core material on Sparta and Crete, then Cleinias and Megillus will be hard put to duck the challenge.

My suggestion will be that it is an account of Lycurgus's lawgiving like Xenophon's that would, on the one hand, have provided a list of topics covered in the legislation - a content - similar to the Athenian's sketch. Xenophon also spells out some of the kinds of moral impact on character which Lycurgus's provisions effected that the Athenian has said he wants to see in an account of them: how it encouraged control of emotions and appetites, how it enforced justice in the citizens' mutual transactions, and so forth. On the other hand, as to an ordering of goods that prioritizes divine over human, Xenophon's version of Spartan legislation does indeed indicate that only to a degree and implicitly. This would explain why the Athenian says it is not all clear to him and most other people, while indicating his acceptance that such an ordering is what the lawgivers were seeking to effect. At the same time, if we suppose that Megillus in particular might be conceived as recognizing the echoes of Xenophon's account of Lycurgus's lawgiving, then Plato might reasonably have represented the Athenian's interlocutors as raising no questions at this point about his long disquisition. Xenophon was, of course, a respected military man who had spent many years of his life in Sparta and had served the Spartans in more than one capacity.

The basic content of the Athenian's account may be broken down into four main areas, clearly demarcated in his wording of the sequence:

1) Marriage, production and upbringing of children, both when they are young and right through their lives.

2) Citizens' acquisition and spending, and the formation and dissolution of partnerships between them.

3) Burial of the dead and their commemoration.

4) Review of the legislation, and appointment of a body to ensure that it coheres and abides by the prioritisation of divine over human goods. 
There is an interesting difference between how 1) is mentioned and how $2), 3)$, and 4) are introduced. The Athenian's reference to marriage and children occurs a little way into a single sprawling sentence, on instructions to be given to the citizens (Leg. 1.631d-632b). It is the first specific (and in this sentence only) example of such an instruction ( Leg. 1.631d-e), but it is not announced as first. Following an initial restatement for the benefit of citizens about the prioritization of divine and human goods in instructions to them, the sentence simply runs on at that point: 'both in regard to marriage unions with one another and after that in the birth and upbringing of the children .... These were not matters which were viewed in Athens as matters falling within the ambit of law (other than provisions for ensuring the formal legality of marriage to secure citizen status of progeny and rights of inheritance). But it is as though the reader will simply be expecting these to be listed as the first topics dealt with in Cretan and Spartan legislation - and distinctively so. By contrast, items 2), 3), and 4) are each of them explicitly introduced in sequence as topics the lawgiver must or will deal with subsequently $($ Leg. 1.632b-d). Their inclusion and ordering seem to be thought to be in more need of flagging up. It is not implied that 3) will be the next topic after 2). Following completion of detail on 2), 3) is introduced with the words: 'until getting through to completion of the whole system' (Leg.1.632c) - which might suggest the possibility of covering other areas between 2 ) and 3) not actually mentioned.

One might infer that Plato expected his readers to be already well aware that marriage, childbirth, and upbringing (with continuing supervision of adult mores) were the topics first addressed in the Spartan regulative system. While we do not know how many accounts of that system may have been in circulation in the first half of the fourth century BC, from which such knowledge might have derived, Aristotle implies quite a number of writings on the Spartan politeia (Pol. 7.14.1333b18-20); there is Xenophon's still extant tract; and Plato at any rate is likely to have known his relative Critias's earlier treatment of the same subject. Critias' book certainly does something to support the inference. In one of the few fragments surviving from his book, he says:

I begin, you see, with the moment of a person's birth: how can he develop the best and the strongest body? The prospective father should exercise and eat healthily and impose a harsh regime on his body, and the future child's mother should exercise and strengthen her body.

Fr. 32 DK, trans. M. GAGARIN and P. WOODRUFF ${ }^{18}$

18 M. Gagarin and P Woodruff (eds), Early Greek Political Thought from Homer to the Sophists (Cambridge: Cambridge University Press, 1995), pp. 262-3. 
Xenophon does little more than amplify Critias's account. 'To begin at the beginning', he starts (Lac. 1.3), 'on the production of children', continuing immediately with discussion of the need for girls of free status to exercise their bodies, and engage in running races and contests of physical strength, just like boys (contrary to norms elsewhere) - if they are to be fit for their greatest responsibility: motherhood. Subsequent chapters deal with boys' education, the athletic competitions in which those who had first reached manhood should engage, and then the Spartan approach to food and drink and the institution of common public meals. For Critias we have no similar material (except for detail on drinking protocol). But it seems likely enough that the same sequence would have been found in his book too.

By contrast, the further topics of legislation to which the Athenian refers 2), 3), and 4) above - are not mentioned in terms suggesting that they would usually be expected at the points in a sequential account of Lycurgus's work that he indicates. Whether there was any such general ordered scheme incorporating them, we are, of course, in no position to know or perhaps even to conjecture. But there is a rough correspondence between 2), 3), and 4), in that order, and the topics of Chapters 7, 9, and 10 respectively in Xenophon, i.e. the chapters which follow those on marriage, production and upbringing of children, and regulation of eating, drinking, and other elements of lifestyle. More specifically:

- Lac. 7.1-4 deals with Lycurgus' prohibition of any activities on the part of the freeborn designed to make money, and the rationale for denying that they will have any need to spend money. This passage might be seen as reflected in the Athenian's reference in 2) to regulating 'the citizens' acquisition and spending' (Leg. 1.632b2-3). He then goes on to give rather more emphasis to mutual relationships, and particularly how far they meet standards of justice, and the rewards and penalties differing conduct of them should attract, anticipating the treatment of exchange and commercial activity in Book 11 (Leg. 11.915d-922a).

- Lac. 9.1-2 discusses the admiration honourable death should evoke, before dwelling at some length on Lycurgus' measures for ensuring misery and shame for the coward. In 3) the Athenian too turns to death. But here the focus is solely on burial practice and commemoration (Leg. 1.632c; cf. $12.958 \mathrm{c}-96 \mathrm{ob})$.

- Lac. 10 overall is devoted to citizen virtue. Its first section is eloquent in its praise of the way Lycurgus encouraged its lifelong pursuit by requiring men to face a contest near the end of the normal lifespan for election to the Council of Elders ( $\gamma \varepsilon p o v \tau i \alpha$ ), and the respect membership attracted because of its responsibility for judging trials on capital charges (Lac. 10.1-3). The 
Athenian's concluding reference in 4) to guardians who will ensure that all the legislation is knit together ( Leg. 1.632c4-d1), seems to adumbrate his 'nocturnal council', a body that 'exercises oversight regarding laws', where age and virtue are qualifications for membership that receive emphasis (Leg. 12.951d-e, 961a).

There is nothing in the Athenian's summary of what he hoped to be told of lawgiving in Crete and Sparta that relates to Chapter 8 of Xenophon's book (dealing with the ways in which Spartan law and its enforcers are invested with the authority that ensures compliance). But the summary is not presented as comprehensive in coverage.

What should we make of these partial and perhaps sometimes tenuous correspondences between the sequences of topics in the two authors? They might of course be no more than the sort of thing that will quite likely happen when two writers deal with the same limited subject - if we had had more fourth century accounts of it we might conceivably have found similar coincidences. Or perhaps Plato may indeed be making some more specific use of Xenophon's identification and sequencing of items of Lycurgan legislation. But it might be felt hard to go beyond that without straying into arbitrary speculation: the sort of thing that in the past filled too many published pages, which we might hope serious scholarship had outgrown.

It has already been argued in broad terms here, however, that Plato needed to assume the availability of an account of Dorian lawgiving such as Xenophon's treatment of Lycurgus to give teeth to the request for explanation of how values are appropriately ordered in such a scheme that his Athenian puts to Cleinias and Megillus at Leg. 1.632d. His reader also needed to be persuaded that his own sketch of the legislation a good lawgiver such as Lycurgus would devise had a basic content that looked Lycurgan or 'Minoan'. An obvious way of doing that would have been to make the content correspond to the main heads of some other account of it that met two conditions: (i) that comparandum must be known or readily available to Plato's likely first readership, and (ii) it must be a treatment of the subject broadly believable for most such early readers, if at all familiar with Spartan institutions or with common beliefs about them (or with Cretan law and society: but fourth century Athenians, at any rate, may well have had only a rather sketchier sense of matters Cretan for the most part). We do not know, of course, whether either (i) or (ii) would have been true of Xenophon's little treatise. But it seems feasible that they may well have been.

The hypothesis proposed, then, is that while the initial topics of the Athenian's summary, marriage, production and upbringing of children, etc. (item 1), are plainly 'Lycurgan', the correspondence in the summary between 
its items 2), 3), and 4), and the topics of Xenophon's Chapters 7, 9, and 10, is nothing coincidental. It is rather Plato's deliberate attempt to highlight in his account of Lycurgus's (and Minos's) lawgiving just those elements (dealing with acquisition and spending, treatment of the dead, constitution of a senior council with specifically legal responsibilities) on which Xenophon had dwelt in the final sections of the main part of his work, particularly in the opening sections of his several chapters. ${ }^{19}$ And the attempt is motivated by Plato's wish to lend some credibility to his suggestion that its entire content is Lycurgan. Perhaps he hoped that if the basic content could fairly readily be seen as more or less Lycurgan, the Platonic ethical preoccupations with which he invested it might similarly be accepted as Lycurgan in spirit.

Indeed, the overall requirement of ensuring that the laws give effect to arrangements that 'follow self-control and justice, not wealth or ambition' (Leg. 1.632c-d: divine, not human goods), could well be regarded as uncontroversially Spartan even if Xenophon never spelled that out. $\Sigma \omega \varphi$ porivin, self-control or restraint or moderation, was often seen as a pre-eminently Spartan virtue. Xenophon suggests as much when he invites his reader to judge whether it is Spartan or some other form of $\pi \alpha 1 \delta \varepsilon i \alpha$ fostered in Greece that produces 'men who are more respectful and having more control over what needs

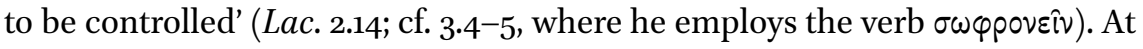
the congress in Sparta held as the tensions which preceded the Peloponnesian War heightened, Thucydides represents the Corinthians as launching proceedings in a speech that famously begins by attributing Spartan $\sigma \omega \varphi p \circ \sigma i v \eta$ to the trust they place in their own political and social system (Thuc. 1.68.1). And Critias for his part had eulogized Spartan sympotic practices as fostering among other things health and $\sigma \omega \varphi p \circ \sigma u ̛ v \eta$, 'neighbour of piety' (Fr. 6.21-2).

He [indeterminately the Cretan and/or Spartan lawgiver] did not set about legislating with an eye to just one part of human goodness - and the least important part at that - but with an eye to goodness as a whole;

19 It is of course possible that one or more other fourth century accounts of the Spartan system besides Xenophon's written prior to the Laws had given the same sort of prominence to Lycurgan laws or institutions that bore some degree of correspondence with items 2), 3), and 4) of the Athenian's summary, perhaps in that same sequence. If that were so, then this section of the paper might be headed 'Plato's debt to Xenophon and/or X and/or Y and/or ...' 
and he sought for the laws he gave them under categories quite different from those used by legislators nowadays. Nowadays everybody seeks to provide himself with whatever it is he personally stands in need of: for one it is Inheritances and Heiresses, for another it is Assault, and so on and so forth. What we say, by contrast, is that the search for laws - for those who approach the search correctly - should follow the procedure we have embarked upon.

Leg. 1.63оe-631a

Plato's Athenian identifies a major difference between the approach to law making taken by Lycurgus and Minos and that taken 'nowadays' - no doubt in contemporary Athens, but presumably elsewhere too. He is explicit about the categories most salient in contemporary legislation: inheritance, assault, and the like. Perhaps the alternatives he credits to the Cretan and Spartan lawgivers have to be inferred from the sequel (Leg. 1.631d-632c). From that it would seem fairly obvious what these are: marriage, birth and upbringing of children, social and economic associations, burial practices before all else (as discussed above in Section 2). ${ }^{20}$ But as the Athenian sees it, there is also a difference between what motivates the selection in each case. Nowadays it is what the individual is in need of: presumably redress if assaulted, and a properly and fairly determined allocation of the family property if inheritance is the issue. It will be indicated in that same sequel what is the prime consideration governing choice of categories in the Cretan and Spartan systems, by contrast. It is that they should secure what is good for well-being at every stage of life, particularly in enabling citizens to cope with their appetites and emotions and the whole gamut of experiences in their relations with others. In other words: the individual's immediate need vs. well-being conceived much more

20 Main structuring topics in the Athenian's implementation of his core programme in Books 6 (last section), 7 and 8, and then passages of Books 11 and 12. The view of the categories to which the Athenian refers that is suggested above was defended a century ago by England, The Laws of Plato: Books I-VI, pp. 210-11. Schöpsdau, Platon: Nomoi, Buch I-III, p. 177 and Meyer, Plato: Laws 1 \& 2, p. 106 (cf. p. 123) argue however that the categories $\left(\varepsilon^{\prime \prime} \delta \eta\right)$ the Athenian has in mind are the species $\left(\varepsilon^{\prime \prime} \delta \eta\right)$ of virtue (identified in those terms at $\left.63^{2} \mathrm{~d}-\mathrm{e}\right)$. And since the first instalment of his own substantive discussion in Book 1 is devoted to the $\dot{\varepsilon} \pi \imath \tau \delta \varepsilon \varepsilon \dot{\mu} \mu \alpha \tau \alpha$ of courage, with the promise of going on from there to deal with a second (indeed he turns to $\sigma \omega \varphi$ pooúv $\eta$ at $635 \mathrm{e}$ ) and a third species of virtue in the same way (but that never actually happens), they have a strong case (cf. Schöpsdau, Platon: Nomoi, Buch I-III, pp. 19o-2). This interpretation has the merit of giving the divine goods the appropriate explicit priority in the approach to legislation recommended by the Athenian. Perhaps there are elements of both sorts of structuring categories in the text. Perhaps Plato never quite chose firmly between them. 
broadly in several dimensions - a conception already recognisable from Xenophon's account of the laws of Lycurgus.

But what form did those laws take? 'During the archaic period laws were written down and publicly displayed in cities all over Greece. ${ }^{21}$ Not so, it seems, in Sparta. Nor does it seem likely that the Spartan laws to which the Athenian refers had the sort of structure - which long remained typical of Greek legislation - found at Athens in Dracon's early law of homicide. There we meet such formulations as: 'Even if a man does not kill another intentionally, he is to go into exile. The kings are to judge guilty of homicide the killer or the planner; and the ephetai are to decide. Reconciliation, if there is a father or brother or sons, is to be by all; or the objector is to prevail.22 By the fourth century the Spartans do appear to have had some written legislation which might well have taken that typical form, to judge from the Athenian orator Lycurgus's mention, in a speech of $33 \mathrm{O} \mathrm{BC}$, of a law of theirs 'covering all who refused to risk their lives for their country, which expressly stated that they should be put to death' (Against Leocrates 129). Lycurgus then proceeded to have the law read out to the court. ${ }^{23}$ But Xenophon's account of the Spartan system as initiated by its legislator does not suggest either use of the kind of formulation employed in other cities for laws or their commitment to writing.

The Laws does not offer much to counteract the impression left by Xenophon. We perhaps might think of a passage in Book 4, where Plato's Athenian is introducing his idea of 'double' laws (a shorter, simpler version in the typical form, and a longer, still in that same form, which however incorporates inter alia quite a lot of explanatory matter). Appropriately enough given the overall approach to law-making he sketched early in Book 1, he chooses an age requirement for marriage for his illustration. Megillus - who has been silent since the end of Book 3 - now intervenes. He says he would opt for the longer formulation, if it were to be enacted in his city as written prescription, despite the Spartan preference for brevity ( $L e g .4 .721 e-722 a)$. His response clearly does not suggest that Sparta had any law having that structure, let alone a written law. The Athenian for his part has said nothing about writing law at this stage. But doubtless Plato can assume that Megillus is well aware of the importance attached to written law in Athens, a city with which - as he is made to stress his family has very close connections (Leg. 1.642b-d; the Athenian will in due

21 M. Gagarin, Writing Greek Law (Cambridge: Cambridge University Press, 2008), p. 110.

22 As translated and cited by Gagarin, Writing Greek Law, p. 96; Greek text at p. $25^{2}$.

23 See M. Gagarin, Early Greek Law (Berkeley, CA: University of California Press, 1986), p. 53 n. 9. Gagarin there and at p. 58 comments helpfully on the probable nature of the Spartan rhetra and their mode of transmission. 
course be pressing insistently for his own part the importance of written law: Leg. 9.858c-859a; cf. 7.822d-823a, 9.87oe-871a, 10.89oe-891a).

It is true that at just that point in Book 9 of the dialogue the Athenian 'refers casually' to Lycurgus as a lawgiver who, like Solon, put things in writing (Leg. 9.858e; cf. Phdr. 258c). ${ }^{24}$ Whether much can be made of this, whether as evidence for actual written laws at Sparta or as Plato's own settled view of the matter, must be doubtful. The explicit reference to Solon is in fact unique in the Laws. One might suspect that it is included just because mention of a lawgiver everyone knew to have put his legislation in writing was needed at this point, Lycurgus's name not being sufficiently convincing on its own. ${ }^{25}$ As to the historical reliability of the Athenian's reference to written legislation in early Sparta, historians who have taken differing stances on the viability of a category of unwritten law as applicable to early Greece - such as Rosalind Thomas (for) and Michael Gagarin (against) - are agreed that (as Thomas puts it):

The 'Lycurgan laws' which supposedly governed the peculiarly Spartan way of life were the unwritten customs enforced by her educational system; the great Spartan 'rhetra', which somehow got written down, was a law about procedure, albeit important constitutional procedure. ${ }^{26}$

Does that evaluation of 'Lycurgan laws' by the historians fit the account of Lycurgus's legislation presented by Xenophon (who does not mention the rhetra)? Certainly 'unwritten customs', enforced by the Spartan educational system and by strongly expressed social expectations (as for example in the shaming of cowards), are what much of Xenophon's text might well seem to

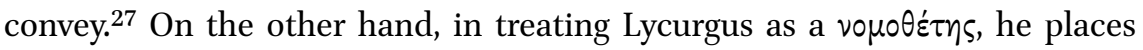
him in the context of a societal practice that from the late fifth century (when

24 See M. Lane, 'Platonizing the Spartan politeia in Plutarch's Lycurgus', in V. Harte and M. Lane (eds.), Politeia in Greek and Roman Philosophy (Cambridge: Cambridge University Press, 2013), pp. 57-77, at p. 68.

25 Interestingly, although both Lycurgus and Solon are mentioned in Book 10 of the Republic as benefactors of their cities, it is only Solon who is there described (along with Charondas) as a lawgiver (Resp. 10.599d-e).

26 R. Thomas, 'Written in stone? Liberty, equality, orality and the codification of law', Bulletin of the Institute of Classical Studies 40 (1995), pp. 59-74, at p. 71; Gagarin, Early Greek Law, pp. 57-8; cf. his Writing Greek Law, pp. 33-8.

27 Gray, Xenophon on Government, p. 46, says: 'Xenophon never suggests that Lycurgus' laws were unwritten.' Nor does he suggest that they were written, unless we are to assume that

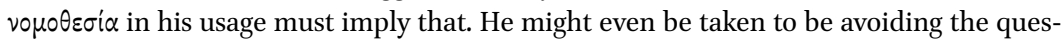
tion. Plutarch notoriously claims that Lycurgus decreed that written laws should not be employed (Lyc. 13.1-2). 


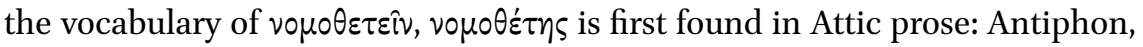
Thucydides, Andocides) is firmly tied to vópos as law, understood as an enforceable rule formally enacted by the community on some particular occasion through the agency of identified or identifiable persons. And as Vivienne Gray points out in her edition of the treatise:

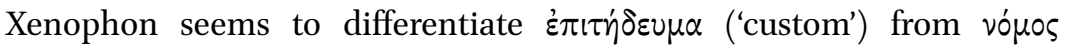
(law') in his introduction, and then to define customs as the products of law when he says that Lycurgus 'laid down laws' that produced

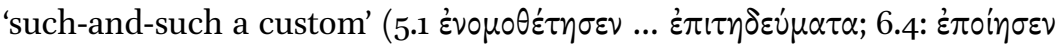

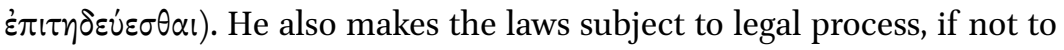
specified penalties. ${ }^{28}$

Plato makes it clear that for his Athenian, too, Lycurgus was a lawgiver. But on the relation of law to custom at Sparta he offers no comment. He does, however, have the Athenian reflect interestingly on that relationship as he proposes to treat it himself in his treatment of what - like Xenophon's Lycurgus - he takes to be the main business of lawgiving. That job is described as 'dealing with marriage, together with the birth and upbringing of children, plus of course education and the appointment of officials in the city' (Leg. 8.842e: topics to which the whole of Books 6 and 7 and the greater part of Book 8 have been devoted). And in the course of his discussion of the earliest stages of upbringing, he says this on the subject of what are generally called 'unwritten customs

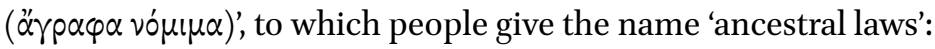

We should neither call these things laws, nor yet pass over them without mention.... If they are the right customs in the first place, and have become second nature, then they envelop, and completely protect, whatever written laws exist at that point; if they are out of key, and get out of true, then ... they bring the whole thing down with them.... Laws (vónovs), habits $(\varepsilon \ddot{\varepsilon} \eta)$, customary practices $(\dot{\varepsilon} \pi \imath \tau \eta \delta \varepsilon \dot{u} \mu \alpha \tau \alpha)$ - whatever anyone calls them $-\ldots$ we must find a place for them. Things of this kind all play a part in holding a city together, and of the two types, neither can endure without the other. Which is why it should come as no surprise if a large number of apparently unimportant customs ( $\left.\nu^{\prime} \mu \tau \mu \alpha\right)$ or even habitual behaviours $(\dot{\varepsilon} \theta i \sigma \mu \alpha \tau \alpha)$ - an incoming tide of them - make our laws a bit on the long side.

Leg. $793 \mathrm{~b}-\mathrm{d}$

28 Gray, Xenophon on Government, p. 45. Legal procedure often remained entirely oral in Greece even when law itself was in writing: Gagarin, Writing Greek Law, pp. 110-21. 
Nor does that exhaust the complexity of law making as Plato perceives it. The Athenian has already stressed the need for regulation of citizens' private lives as well as the city's public and communal life, particularly women's lives (Leg. 6.779d-781d). But when it comes to instructing pregnant women and nurses carrying babies and infants on how to move around so as best to foster the child's development, he holds back from legislation, for fear of its being ridiculed and ignored. Instead he decides to concentrate on persuading householders of the importance of proper control of the private sphere. Then, he says:

That may prompt the householder to adopt these rules that we have suggested for himself; and if he does adopt them, then he may make a good job of running his own household - and the city into the bargain - and in that way achieve well-being.

Leg. $7.79 \mathrm{ob}$

At the end of Book 7 , when about to launch on the topic of hunting as a pursuit for the young, he recurs to the general approach there advocated:

The lawgiver's task seems to have to go beyond merely putting laws in place and then calling it a day; something more is called for, over and above the laws, something whose nature puts it midway between advice and actual law - not the first time this has cropped up in our discussion, for example when we were talking about the upbringing of very young children.

Leg. $7.822 \mathrm{~d}-\mathrm{e}$

What is needed is explanation, with a stress on what the lawgiver thinks fine $(\kappa \alpha \lambda \dot{\alpha})$ or the opposite in any practice - expressed in criticism and praise, which should be valued and treated as directives $($ Leg. $7.823 \mathrm{C}-\mathrm{d}) .{ }^{29}$

In sum, the Plato of the Laws endorses Lycurgus's main focus on laws dealing with the proper development, conduct, and treatment of human beings at every stage of the life cycle. If from Xenophon we form the impression that Spartan law was primarily concerned with sound customary practices $(\dot{\varepsilon} \pi \imath \tau \eta-$ $\delta \varepsilon \dot{v} \mu \alpha \tau \alpha)$ and the like, then the Laws takes the same view of what should be

29 Such explanations would presumably be akin to the 'preludes' the Athenian outlines in Book 4 (Leg. 4.719e-724a). But in Books 6 to 8 the notion of preamble is notable by its absence, except for one instance early on (on choice of marriage partner: Leg. 6.772e-773c). In general, these books seem to belong to a different stratum of composition from Book 4 and Books 9-11 (which do employ preludes so named). 
law's emphasis. But Plato has reflected more fully and with much more conceptual sophistication both on how law sensu stricto is best formulated, and how it should relate to less formal kinds of advice, encouragement (and discouragement), and persuasion.

\section{$4 \quad$ Conclusion}

No reader of the Laws can be in doubt that it is dense with material echoing and often engaging with ideas, themes, and cultural and institutional forms given expression both in Greek writings of other provenance and in actual Greek practice past and present, as well as with reference of various kinds to his own huge oeuvre. As Shorey put it, 'allusions to methods and ideas of the dialectical dialogues, and explicit solutions of problems dramatically presented in the minor dialogues, make the work almost a complete compendium of the Platonic philosophy'.30 Often reconstruction of such engagement often has to be a conjectural business, subject to obvious hazards. ${ }^{31}$ The opening section of Book 1, together with its relationship to Xenophon's treatise on Sparta, has perhaps not previously been viewed from the angle whose fruitfulness has been suggested here. Further debate is awaited.

30 P. Shorey, 'Plato's Laws and the unity of Plato's thought', Classical Philology 9 (1914), pp. $345^{-69}$, at p. 347 .

31 For a previous exercise of mine in this genre that engages with different material in the Laws, see 'Friendship and justice in the Laws', in G. Boys-Stones, D. El Murr, and C. Gill (eds.), The Platonic Art of Philosophy (Cambridge: Cambridge University Press, 2013), pp. $283^{-}-97$. 